\title{
Histone H1.0
}

National Cancer Institute

\section{Source}

National Cancer Institute. Histone H1.0. NCI Thesaurus. Code C162798.

Histone H1.0 (194 aa, $21 \mathrm{kDa}$ ) is encoded by the human H1-0 gene. This protein plays a role in terminal differentiation and chromatin structure regulation. 